\title{
Gender Mainstreaming in E-government Services Adoption - A case of E-citizen Portal in Kenya
}

\author{
John O. Sagimo \\ School of Computing and Informatics, \\ University of Nairobi, Kenya
}

\author{
Elisha O. Abade \\ School of Computing and Informatics, \\ University of Nairobi, Kenya
}

\begin{abstract}
This study examines how the concept of gender mainstreaming could influence the adoption of e-government services in Kenya, which like many other developing countries, the Kenyan e-government initiatives has faced a number of challenges since its inception. The study utilizes and expands on Technology Acceptance Model to explore the adoption of e-government services in the Siaya County of Kenya. A simple random sampling technique was used to select a sample size from the population and a questionnaire was used to collect data from the participants. Analysis of the demographic data was done to test the research hypothesis using descriptive statistics of frequency counts and percentage. The major findings of the study revealed that men are potential adopters of e-government services. This is exhibited by a positive correlation that was found after a regression done on gender in relation to E-government adoption. The findings of this study are meant to provide a better understanding of mainstreaming gender in order to engender the adoption of e-government services.
\end{abstract}

\section{General Terms}

Gender Mainstreaming, E-government services adoption

\section{Keywords}

E-government, Gender, ICT Policy, E-service delivery, TAM, Technology Adoption, Kenya, E-citizen portal

\section{INTRODUCTION}

E-Government is a fundamental element in the modernization of Government. It provides a common framework and direction across the public sector and enhances collaboration within and among public sector organizations and institutions, between Government and the business community, and between Government and the citizens that it serves in the implementation of Government Policies. It also identifies ways of developing the skills needed by public servants to realize the new opportunities offered by ICT advancement such as the internet. [1]

The ministry of information technology of Kenya suggests that E-government can be segmented into what are known as primary delivery models; [2] the relationship between government and citizens (G2C), electronic interactions between government agencies and private businesses (G2B), relationship between governmental organizations $(\mathrm{G} 2 \mathrm{G})$, and the relationship between government and its employees (G2E) [1].This study focuses on the delivery model of government and citizens (G2C). The growing interest in e-Government raises the question of how the Kenyan government can increase citizen adoption and usage of their online government services. [3] Applauds that E-Government becomes especially important given its potential to reduce costs and improve service compared with alternative traditional modes. [4]Outlines that the success of such initiatives is dependent not only on government support, but also on gender factor to accept and adopt those e-government services. Government decision makers, therefore, need an understanding of the factors that would encourage use of e-government services rather than more traditional service delivery methods. [4]

As in previous years, the United Nations 2014 Survey [5] shows that Europe continues to lead with the highest regional E-Government Development Index (EGDI) followed by the Americas led by the United States of America (ranked 7th globally); Asia led by the Republic of Korea; Oceania led by Australia; and Africa led by Tunisia (ranked 75th globally). Nevertheless, the 2014 Survey [5] shows that each geographica region exhibits high internal diversity. Progress in Africa remains relatively slow and uneven. The regional EGDI average in Africa is 0.2661. Six countries (Tunisia, Mauritius, Egypt, Seychelles, Morocco and South Africa) have EGDI values above the world average of 0.4712 , placing them among the top 50 per cent of the world. On the other hand, about 30 per cent (16 countries) of the 54 African countries are at the bottom 10 per cent of the world ranking.

Gender factor was observed in this study to be an important catalyst of e-Government adoption. By investigating e-citizen portal, already available and used in Kenya, several ways are recommended in which the government can increase gender equality and thus encourage the adoption of this new and potentially significant mode of e-government service. The proposed research model takes in account issues of gender, egovernance policies and strategies, access to ICTs, education level and ICTs access which are seen to influence the use of eGovernment services.

\section{RELATED WORK}

[6] Defined gender as a hierarchical separation between women and men embedded in both social institution and social practices. [6] Argues that gender can be employed as a descriptive variable as well as an explanatory variable. A number of researchers [6]; [7]; [8]; [9]; as referenced by [6] have investigated the role of gender in the adoption and usage of technology. Previous studies have revealed that gender has an important effect and role when considering technology adoption and usage in organizational context. [8] Showed that male users use a computer more than females to show gender as one of the most important variables when adopting technology. According to [8] gender differences have been shown to exist in technology-adoption contexts. Furthermore, gender significantly moderates the influence of the determinants on behaviour intention. For example, [8] found that the effect of perceived usefulness on behaviour intention was moderated by gender. This research has been guided by [10] proposition that gender (as a social variable) can be considered as an 
independent variable to explain the differences between adopters and non-adopters of technology, in this case egovernment.

\subsection{The concept of gender mainstreaming}

[11] Defines gender mainstreaming is the process of assessing the implications for women and men of any planned action, including legislation, policies or programmes, in all areas and at all levels. [11] claims that it is a strategy for making women's as well as men's concerns and experiences an integral dimension of the design, implementation, monitoring and evaluation of policies and programmes in all political, economic and societal spheres so that women and men benefit equally and inequality is not perpetuated. [11]The ultimate goal is to achieve gender equality.

\subsection{E-government Projects and Gender}

[12] Illustrates that the emergence of information and communication technology (ICT) has affected the functions and roles of governments' worldwide. E-governance has been one of the main impacts of ICT. Many governments have realized the benefits of e-governance and have started offering their services through the internet. [12]

[12] Views that implementation of e-Government projects either fails or succeeds. Countries that have implemented e-Government successfully prove that in such countries there has been a well-authored strategies and implementation plans. [12] Gives examples of countries that have taken this approach as Singapore which has an e-Government Action Plan (eGap), Tanzania and Mozambique which have put in place e-Government implementation strategies and roadmaps [13]. African governments have understood and appreciated the contribution of e-government to the government agenda. [14] Indicates that at the moment, strategic plans have been initiated in Egypt, Senegal, Mozambique, South Africa and Kenya.

\subsection{Technology Acceptance Model}

A number of studies have investigated the adoption of egovernment services using technology acceptance theories and models, such as the Theory of Reasoned Action (TRA) , the Theory of Planned Behavior (TPB), the Technology Acceptance Model (TAM), the Diffusion of Innovation (DOI) and the Unified Theory of Acceptance and Use of Technology (UTAUT) as documented by [15]

Technology Acceptance Model is recommended in order to achieve the objectives of this research. [16] States that TAM has been extensively used to analyze citizen's acceptance in various e-government researches. [16] Confirms that it is based on the belief that individual factors affecting the users decision whether to accept or reject an e-government service can be identified and measured. [16] TAM sees perceived ease of use and perceived usefulness as fundamental determinants of user acceptance. These two variables influence intention to use an egovernment service, which, in turn, correlates with actual use. [16] Confirms that the model uses measurement scales for both ease of use and usefulness

Although it has already been used in other e-government acceptance studies, [15], UTAUT does not seem to be easily adapted for this study. The model is best used to measure technology acceptance in companies. Two of its six variables rely heavily on the technology being introduced in an organization. [17] Outlines some of the criteria suggested to measure "social influence" include help of the senior management, and organizational support for the new technology. [17] States that "Voluntariness of use" measures whether technology is compulsory in the job, to what extent it is required by the boss, or expected by supervisors

\subsection{Conceptual Model}

This model indicates that gender, design for e-governance policies and strategies, and e-service delivery that have a significant impact on both perceived usefulness and perceived ease of use to adopt e-government services.

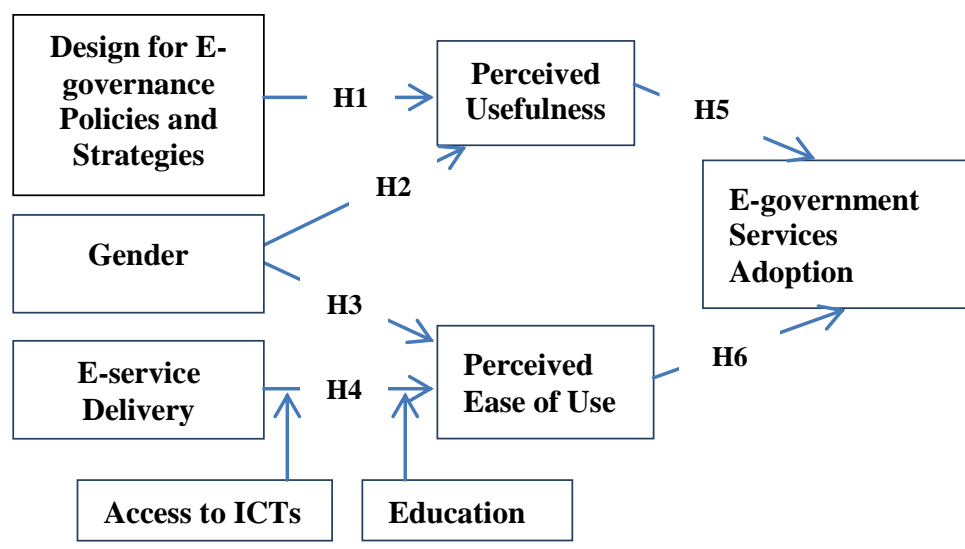

Figure 1: Conceptual Model

\section{METHODOLOGY}

\subsection{Research Design}

There are three designs that have traditionally been used in scientific research. These are descriptive, correlational and experimental designs. [18] Suggests that descriptive design studies are commonly used when examining social issues that exist in communities.

A quantitative research methodology using a survey questionnaire was selected as the primary data collection method for this study. This research design was used to qualitatively explore gender factors that affect the adoption of e-government services in Kenya, for example, education, egovernance policies and strategies and access to ICTs to use such services.

A survey questionnaire was utilized as it is inexpensive, less time consuming and has the ability to provide both quantitative scale and qualitative data from a large research sample. These are the sentiments of [19] as cited by [16]

\subsection{Target population and Sample Size}

Using survey research method, both quantitative and qualitative data was collected from a cross section of female and male inhabitants residing in the rural areas of Siaya County. The population consisted of women and men aged between 18-60 years. According to statistics found in Kenya open data; there are a total of 47 counties in Kenya. This study focused on Siaya County which is located in Nyanza and constitutes 6 constituencies (Ugenya, Alego, Ugunja, Gem, Bondo and Rarieda). Siaya has a total population of 842,304 people.

The criteria used to determine the appropriate sample size for this study consisted of the level of precision, the level of confidence and the degree of variability in the attributes used. According to [20] there are several approaches to determining the sample size. These include using a census for small populations, imitating a sample size of similar studies, using 
published tables, and applying formulas to calculate a sample size. This study relied on published tables and application of formulas to calculate the sample size.

Table 1: Sampling procedures

\begin{tabular}{|l|l|l|l|l|}
\hline \multirow{2}{*}{$\begin{array}{l}\text { Size of } \\
\text { Population }\end{array}$} & \multicolumn{4}{|l|}{ Sample Size(n) for precision (e) of: } \\
\cline { 2 - 5 } & $\mathbf{\pm 3 \%}$ & $\mathbf{\pm 5 \%}$ & $\mathbf{\pm 7 \%}$ & $\mathbf{\pm 1 0 \%}$ \\
\hline 15,000 & 1,034 & 390 & 201 & 99 \\
\hline 20,000 & 1,053 & 392 & 204 & 100 \\
\hline 25,000 & 1,064 & 394 & 204 & 100 \\
\hline 50,000 & 1,087 & 397 & 204 & 100 \\
\hline 100,000 & 1,099 & 398 & 204 & 100 \\
\hline$>100,000$ & 1,111 & 400 & 204 & 100 \\
\hline $\begin{array}{l}\text { Sample size for } \pm 3 \%, \pm 5 \%, \pm 7 \%, \pm 10 \% \text { Precision Levels } \\
\text { where Confidence level is } 95 \% \text { and } \mathrm{P}=.5\end{array}$ \\
\hline
\end{tabular}

\section{Source (Israel, Glenn D. 1992)}

Since Siaya county has a large population size of above 100,000 and the variability in the proportion that would adopt e-government was unknown, a precision level of \pm 10 , Confidence level of $95 \%$ and an estimated proportion of $\mathrm{p}=0.5$ were used for the sample needed.

\subsection{Data Collection Tools and Techniques}

The purpose of a tool or instrument in research is to measure the variables of study. [18] Informs that the validity and reliability of data are functions of the quality of the tools used in collecting information. The type of measurement tool used depends on the design and type of study. To guarantee collection of quality data, [18] confirms that appropriate data collection techniques must be applied. The term 'technique' refers to the way a given tool is applied to collect information. For example, interviewing, as a data collection technique requires the use of an interview guide.

The data collection instrument that was used in the study was a questionnaire. The questionnaire construction began by anticipating possible sources of errors which might make the respondents give erroneous information or even fail to answer a question completely. This was done to minimize threats to reliability and validity that may be present in the study. It was ensured that the operational definitions matched the theoretical concepts and that the sample population will answer the questions adequately. In safeguarding relevance of the study the objectives were explained, justified and made clear to the respondents by using word of mouth and a short introductory statement on top of the questionnaire. This was also done to convince the respondents on the importance of the research so as to give accurate responses.

\subsection{Data Analysis}

In scientific inquiry, notes [18], that data is transformed into knowledge when it is properly analyzed, interpreted and the interpretations given meaning. [18], recognizes four levels of measurement scales. The nominal scale, ordinal scale, interval scale and ratio scale. The research data was categorized into nominal scale that is considered to be the lowest level of measurement of a variable.

The technique that was used in data analysis was partial correlation. This technique was chosen because of its ability to estimate the relationship between the predictor and criterion variable. In order to see the actual relationship between the variables without the influence of other variables, controlling the effects of other variables is necessary.

Analysis of the demographic data was done to test the research hypothesis using descriptive statistics of frequency counts and percentage. Descriptive statistics as [18] confirms, include measures of central tendency (mean, mode, median,) measures of dispersion (variance, standard deviation and range) and measures of association. The analysis also described the shape of the distribution of the main variables using indices such as skewness and kurtosis. Data was further summarized visually using frequency tables, graphs, and charts.

A correlation analysis of variables was carried out to confirm the influence of the variables on the adoption. The tools used for analysis included Microsoft Excel 2010 and SPSS 20.0

\subsection{Reliability and Validity}

Reliability is the assessment of the degree of consistency between multiple measures of a variable [18]. It is designed to demonstrate the extent to which the operations in a study such as data collection can be repeated and similar results are obtained and the attributes being measured is believed not to have changed in the interval between measurements even if the test is administered by different people using same or alternative forms of the test. A measure is deemed reliable if an individual's score on the test is the same when given more than once in similar test and under similar circumstances. A reliable instrument or test must meet two conditions; it must measure a single dimension and it must have a small random error.

In this study Cronbach's alpha coefficient which is the most common measure of scale of reliability was used to measure reliability of the questionnaire. This test was selected over the other tests on the strength that it has been applied to similar studies, [8]. The generally agreed lower limit for Cronbach's alpha is $0.7,[20]$.

\section{RESULTS AND DISCUSSIONS 4.1 Response rate}

The number of questionnaires distributed was 149 and out of this number only 129 were found to be valid for use in the analysis process. This represented a response rate of $87 \%$.

\subsection{Demographics}

\subsubsection{Gender of participants}

Participants were asked to tick the gender category appropriate to them (see table below). A total of 129 or $(86.6 \%$ ) participants responded to the question. 20 participants that make $13 \%$ of the sample did not respond. $47 \%$ of the respondents were female (70 responses) and $40 \%$ constituted the male (59 responses). Majority of the females and males were from Bondo Constituency

Table 2: Gender of participants (Source: Research Data, 2016)

\begin{tabular}{|l|l|l|l|l|}
\hline & Frequency & Percent & $\begin{array}{l}\text { Valid } \\
\text { Percent }\end{array}$ & $\begin{array}{l}\text { Cumulative } \\
\text { Percent }\end{array}$ \\
\hline Female & 70 & 47.0 & 54.3 & 54.3 \\
\hline Male & 59 & 39.6 & 45.7 & 100.0 \\
\hline Total & 129 & 86.6 & 100.0 & \\
\hline Missing & 20 & 13.4 & & \\
\hline Total & 149 & 100.0 & & \\
\hline
\end{tabular}




\subsubsection{Income Status of the Participants}

The study had three categories of income status, those who had no income at all, those who had and those who were not willing to disclose their income status. 36 female and 40 male participants had income while 27 female and 16 male had no income at all. Only 10 of the participant were not willing to disclose their income status. The income status variable was crucial in this study since it was used to determine if it had influence on the access to ICTs

Table 3: Income Status of Participants (Source: Research Data, 2016)

\begin{tabular}{|l|l|l|l|l|l|}
\hline & & \multicolumn{3}{|l|}{ Income Status } & \multirow{2}{*}{ TOTAL } \\
\hline & & N/A & NO & YES & TOT \\
\hline Gender & Female & 7 & 27 & 36 & 70 \\
\hline & Male & 3 & 16 & 40 & 59 \\
\hline Total & & 10 & 43 & 76 & 129 \\
\hline
\end{tabular}

\subsubsection{Age of the participants}

The highest number of respondents was of the age between 26 to 35 years. This was followed by the age bracket of 36 to 45 with 33 respondents. There were 18 respondents within the age bracket of 18 to 25 and 15 respondents within the age bracket of 46 to 60 . Only one male did not indicate his age. This shows that the majority of the respondents of this study were majorly youths who had interest in e-government services or were already using the services.

Table 4: Age of Participants (Source: Research Data, 2016)

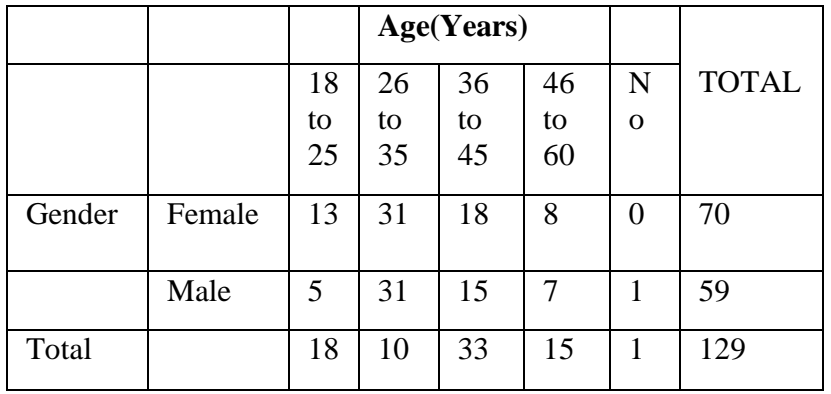

\subsubsection{Constituencies of the participants}

This study focused on Siaya County which is located in Nyanza and constitutes 6 constituencies (Ugenya, Alego, Ugunja, Gem, Bondo and Rarieda). The Independent Electoral and Boundaries Commission (IEBC) of Kenya 2015 report indicate that Siaya has a total population of 842,304 people. Responses were received from all the constituencies. From Bondo constituency, $25.7 \%$ of participants were female and $50.8 \%$ of participants were male making a total of 48 respondents. In Alego constituency, $11.8 \%$ of participants were female and $15.3 \%$ of participants were male making a total of 17 respondents. In Ugenya, there were 14 Female and 16 male respondents. In Ugunja we had 7 female and 5 male respondents. In Gem constituency, $14.3 \%$ of participants were female and $10.2 \%$ of participants were male making a total of 16 respondents. Rarieda constituency had 13 Female and 7 male respondents.

\subsection{Descriptive Statistics of the Independent Variables}

This study consisted of three independent variables namely gender, E-service delivery and Design for E-governance Policies and Strategies. The descriptive statistics in this study was based on cross tabulations between the dependent variables and independent variables to establish how each of the independent variable will affect their association with the dependent variable. A non-parametric test (Chi-square) test for goodness of fit was applied to explore the proportion of cases that fall into the various categories of the variables and relationship between them.

\subsubsection{Gender}

The result indicates that out of 129 responses, 70 responses were female and 59 male. $36.4 \%$ of females had basic computer training while $33.6 \%$ of them had no basic training in computer. On the other hand, 55.9\% of male had basic computer training and $44.1 \%$ of them had no basic training in computer

When the percentages of those who had basic training in computer were combined, the results showed that $51.9 \%$ of both male and female had computer training and $48.1 \%$ of the total gender had no basic training in computer. This shows that majority of the gender had computer training while minority had no computer training.

However, when chi-square test was conducted to verify whether the proportion of women and men had a difference in basic computer training, the results indicates that there was no significance difference in basic computer training between the two proportions (male and female). This is because the chiresults shows a significance value of 0.405 which is above the recommended significance value of 0.05 . This implies that both female and male had equal basic training in computer.

\subsubsection{E-Service Delivery}

The result indicates that out of 129 responses, 70 responses were female and 59 male. $54.3 \%$ of females feel that e-citizen portal doesn't provide the precise information they need, $14.3 \%$ did not answer the question while $31.4 \%$ confirmed that ecitizen provided information that they needed. On the other hand, $54.2 \%$ of male felt that e-citizen portal doesn't provide the precise information they need while $13.6 \%$ did not choose either yes or no and $31.8 \%$ of them confirmed that e-citizen provided information that they needed.

When the percentages of those who felt that the e-citizen portal provided the information they needed were combined, it totaled to $54.3 \%$ while $31.8 \%$ of the total gender felt that e-citizen portal doesn't provide the precise information they need. This shows that majority of the gender both male and female felt that e-citizen portal didn't provide the precise information they needed. A chi-square test was conducted showing statistical results $(\mathrm{X} 2, \mathrm{df}=2, \mathrm{n}=129$, Asymp.sig $=0.991)$ that indicated there was no difference between the observations for both the gender. This result answers the research question, 'Does the ecitizen portal provide the basic services and public information required by each gender?'

\subsubsection{Design for E-governance Policies and Strategies}

The result indicates that out of 129 responses, 70 responses were female and 59 male. $68.6 \%$ of females were not conversant with the current Kenyan ICT policy, $24.3 \%$ of them 
were conversant while only $7.1 \%$ were not willing to declare their opinion. On the other hand, $74.6 \%$ of male were not conversant with the current Kenyan ICT policy while $16.9 \%$ did not choose either yes or no or only $8.5 \%$ of them were conversant with the ICT policy.

When the percentages of those who were not conversant with the current Kenyan ICT policy were combined, it totaled to $71.3 \%$ while only $17.1 \%$ of the total gender were conversant with the ICT policy. This shows that majority of the gender both male and female had no clue of what ICT policy was all about.

A chi-square test was conducted to verify whether the proportion of women and men had the same view on the design for e-governance Policies and Strategies, the results indicates that both men and women were not conversant with the current Kenyan ICT policy. Statistical results $(\mathrm{X} 2, \mathrm{df}=2, \mathrm{n}=129$, Asymp.sig $=0.023$ ) indicates that there is no difference between observed and expected values.

\subsection{The analysis of moderating factors on independent variables}

\subsubsection{ICT access}

A non-parametric test (Chi-square) test for goodness of fit was applied to explore the proportion of cases that fall into the various categories of the variables and relationship between them. A chi-square test was conducted to verify whether ICT access had a positive effect on e-service delivery, the results indicates that there was indeed significance in the relationship between the two variables. Statistical results $(\mathrm{X} 2, \mathrm{df}=4, \mathrm{n}=$ 149, Asymp.sig=0.000) indicates that there is difference between observed and expected values.

\subsubsection{Education Level}

Another non-parametric test (Chi-square) test for goodness of fit was applied to explore the proportion of cases that fall into the various categories of the variables and relationship between them. A chi-square test was conducted to verify whether education level had a positive effect on e-service delivery, the results indicates that there was indeed a positive significance in the relationship between the two variables.

Statistical results $(\mathrm{X} 2, \mathrm{df}=4, \mathrm{n}=149$, Asymp.sig $=0.003)$ indicates that there is a difference between observed and expected values

\subsection{Hypothesis Testing}

The study had six hypotheses that were tested by conducting simple linear regression on the independent and dependent variables.

H1 Design for E-governance Policies and Strategies has a significant influence on perceived usefulness. The Pearson's correlation coefficient between Design for E-governance Policies and Strategies and perceived usefulness as shown in Table 5 is positive and significant, the significance of each of the variable is less than 0.05 at 0.000 hence the values are significant. This complies with the hypothesis that design for egovernance policies and strategies will have positive influence on perceived usefulness of e-government services.
Table 5: H1 (Source: Research Data, 2016)

\begin{tabular}{|l|l|l|l|l|l|}
\hline & \multicolumn{2}{|l|}{$\begin{array}{l}\text { Unstandardized } \\
\text { Coefficients }\end{array}$} & $\begin{array}{l}\text { Standardized } \\
\text { Coefficients }\end{array}$ & & \\
\hline Model & B & Std.Error & Beta & $\mathrm{t}$ & Sig. \\
\hline Constant & 2.0 & 0.242 & & 8.276 & .000 \\
\hline $\begin{array}{l}\text { Design for E- } \\
\text { governance } \\
\text { Policies and } \\
\text { strategies }\end{array}$ & 0.079 & 0.94 & 0.069 & .838 & .403 \\
\hline Dependent Variable: Perceived Usefulness & & & \\
\hline
\end{tabular}

H2 Gender has a significant influence on perceived ease of use. The Pearson's correlation coefficient between gender and perceived ease of use as shown below is positive and significant, significance of each of the variable is less than 0.05 at 0.000 hence the values are significant. The hypothesis that women will rate the perceived usefulness of e-government services higher than men is true and can be observed from the regression table which shows that $30 \%$ of the females find it so easy to use the e-citizen portal compared to $10 \%$ of men who find it easy to use. Table 6 shows the results.

Table 6: H2 (Source: Research Data, 2016)

\begin{tabular}{|l|l|l|l|l|l|}
\hline & \multicolumn{2}{|l|}{$\begin{array}{l}\text { Unstandardized } \\
\text { Coefficients }\end{array}$} & $\begin{array}{l}\text { Standardized } \\
\text { Coefficients }\end{array}$ & & \\
\hline Model & B & Std.Error & Beta & t & Sig. \\
\hline Constant & 1.943 & 0.359 & & 5.405 & .000 \\
\hline Gender & 0.529 & 0.233 & 0.197 & 2.265 & .025 \\
\hline
\end{tabular}

Dependent Variable: E-citizen portal ease of use

H3 Gender has a significant influence on usefulness. The Pearson's correlation coefficient between gender and perceived usefulness as shown below is positive and significant, significance of each of the variable is less than 0.05 at 0.000 hence the values are significant. The hypothesis that men will rate the perceived usefulness of e-government services higher than women is true. Table 7 shows the results.

Table 7: H3 (Source: Research Data, 2016)

\begin{tabular}{|l|l|l|l|l|l|}
\hline & \multicolumn{2}{|l|}{$\begin{array}{l}\text { Unstandardized } \\
\text { Coefficients }\end{array}$} & $\begin{array}{l}\text { Standardized } \\
\text { Coefficients }\end{array}$ & & \\
\hline Model & B & Std.Error & Beta & $\mathrm{t}$ & Sig. \\
\hline Const. & 2.237 & 0.247 & & 9.060 & .000 \\
\hline Gender & -0.08 & 0.160 & 0.005 & -.051 & .959 \\
\hline
\end{tabular}

Dependent Variable: Does the portal provide information you need

H4 E-service delivery; the association of e-service delivery with perceived ease of use was moderated by ICTs access and education level, both moderators were expected to have a strong positive effect on relationship between the variables. Indeed, the moderators did have a positive effect on the association as claimed. The Pearson's correlation coefficient 
between e-service delivery and perceived ease of use as shown below is positive and significant, significance of each of the variable is less than 0.05 at 0.000 hence the values are significant.

Table 8: H4 (Source: Research Data, 2016)

\begin{tabular}{|l|l|l|l|l|l|}
\hline & \multicolumn{2}{|l|}{$\begin{array}{l}\text { Unstandardized } \\
\text { Coefficients }\end{array}$} & $\begin{array}{l}\text { Standardized } \\
\text { Coefficients }\end{array}$ & & \\
\hline Model & B & Std.Error & Beta & $\mathrm{t}$ & Sig. \\
\hline Constant & 1.724 & 0.380 & & 4.536 & .000 \\
\hline $\begin{array}{l}\text { E-service } \\
\text { Delivery }\end{array}$ & 0.284 & 0.163 & 0.142 & 1.743 & .983 \\
\hline
\end{tabular}

Dependent Variable: E-citizen portal ease of use

H5 Perceived usefulness has a significant influence on egovernment services adoption. The Pearson's correlation coefficient between perceived usefulness and e-government services adoption as shown in Table 9 is positive and significant, the significance of each of the variable is less than 0.05 at 0.000 hence the values are significant. The results confirm the hypothesis that perceived usefulness will have a significant influence on e-government services adoption.

Table 9: H5 (Source: Research Data, 2016)

\begin{tabular}{|l|l|l|l|l|l|}
\hline & \multicolumn{2}{|l|}{$\begin{array}{l}\text { Unstandardized } \\
\text { Coefficients }\end{array}$} & $\begin{array}{l}\text { Standardized } \\
\text { Coefficients }\end{array}$ & & \\
\hline Model & B & Std.Error & Beta & t & Sig. \\
\hline Constant & 1.697 & 0.276 & & 6.138 & .000 \\
\hline $\begin{array}{l}\text { Perceived } \\
\text { Usefulness }\end{array}$ & 0.122 & 0.65 & 0.153 & 1.874 & .063 \\
\hline \multicolumn{7}{|l|}{ Dependent Variable: E-government services adoption } \\
\hline
\end{tabular}

H6 Perceived ease of use has a significant influence on egovernment services adoption. The Pearson's correlation coefficient between perceived ease of use and e-government services adoption as shown in Table 10 is positive and significant, the significance of each of the variable is less than 0.05 at 0.000 hence the values are significant. The result confirms the hypothesis that perceived usefulness will have a significant influence on e-government services adoption.

Table 10: H6 (Source: Research Data, 2016)

\begin{tabular}{|l|l|l|l|l|l|}
\hline & \multicolumn{2}{|l|}{$\begin{array}{l}\text { Unstandardized } \\
\text { Coefficients }\end{array}$} & \multicolumn{2}{l|}{$\begin{array}{l}\text { Standardized } \\
\text { Coefficients }\end{array}$} & \\
\hline Model & B & Std.Error & Beta & $\mathrm{t}$ & Sig. \\
\hline Constant & 3.928 & 0.144 & & 27.253 & .000 \\
\hline $\begin{array}{l}\text { E-citizen portal } \\
\text { ease of use }\end{array}$ & 0.085 & 0.051 & 0.135 & 1.657 & .100 \\
\hline \multicolumn{7}{|l|}{ Dependent Variable: E-government services adoption } \\
\hline
\end{tabular}

\subsection{Discussions of Findings}

This study confirms many of the hypotheses proposed in the model. Design for e-governance policies and strategies,
E-service delivery, Perceived ease of use and usefulness and ultimately the adoption of e-government services.

The proposed model had six constructs, where all the independent constructs reported positive and significant correlation with both perceived usefulness and perceived ease of use. The results of each constructs are in response to the objectives of this study which stated as follows,

To gain better understanding of how gender influences the adoption of e-government services in Kenya, particularly in Siaya County

To determine the constituents of enabling/disabling environment's for access and use of e-government services by each gender' as the second objective

The findings are as discussed below

\subsubsection{Gender}

The social attributes associated with being male and female and the relationships between women, men, girls and boys, as well as the relations between women and those between men. [21]

To explain gender toward e-government adoption and use, it was hypothesized that men will rate both the perceived usefulness and perceived ease of use of e-government services higher than female. According to the findings, this hypothesis was supported since there was significance difference between men and women when it comes to rating the perceived usefulness and perceived ease of use of e-government services. The outcome of this research is in line with previous studies that states there are gender gaps when it comes to use and access of ICTs. Therefore, this study confirms that men are likely to be potential adopters of e-government services than their female counterparts.

\subsubsection{E-service delivery}

From the above study and analysis of findings it is evident that E-service delivery plays a major role in E-government adoption. To confirm this, respondents suggested that the following should be done to the current e-services;

i. All necessary services e.g. id registration and replacement should be provided

ii. Online payment of these services should be enabled

Other services that were recommended included, company or business registration, Public land disposal tribunals, Police services, (security) tax department. Metrology, disasters and general government services

Therefore, from the findings, it would be safe to suggest that Egovernment services offered have to be accessible for the initiative to succeed. Furthermore a report by [21] suggests prioritizing of e-services that address the specific needs of both women and men and are more responsive to gender equality issues. [21] This is particularly relevant for local service delivery, as women, stakeholders and communities usually have much closer contact with local government authorities than other levels of government and often have better opportunities to express their needs and concerns at the local level.

\subsubsection{Design for e-governance policies and strategies}

Previous evidence indicates that most national e-governance strategies and policies were designed on a "supply driven" basis, with little to no inputs from non-State stakeholders [21]. 
From this study and analysis of findings it is evident that design for e-governance policies and strategies plays a major role in Egovernment adoption. Both men and women argue that the policies and strategies in place don't equally represent their interest. Policies that exist put obstructions like: un-necessary control of information flow, un-authorized access to information by government officials, and prohibited access of information by the general public for fear of confidentiality breach. Some of these guidelines slow down E-government adoption in the public sector [21]. 96.9\% of female respondents and $86.3 \%$ of male respondents strongly agree that gender equality is not considered when it comes to ICT formulation. Many studies outlined in the literature do not support inclusion of gender in their ICT policy. For example, In Mozambique, existing policies do not include any treatment of social issues, including gender [21]. In support of the previous researches, this study confirms that there is a strong need for inclusion of gender factor when it comes to strategizing and formulating ICT policies.

\section{RECOMMENDATIONS AND SUGGESTIONS}

There are many ways in which Kenyan government can increase perceived usefulness. One is through the e-citizen portal: the information in the website has to be accurate, timely, informative, updated and relevant to citizens' needs. A good site not only contains sufficient information but also designed to be user friendly for all level of users. The website should have a search and help features to enable users quickly and effortlessly find relevant information, provide for two way communications between users and the site; and also respond quickly to users' search and browsing needs. Kenyan government should also elicit and analyze citizens' feedback about their site. These valuable feedbacks will enable government to redesign sites to present information and services in a way that is easy for citizens to utilize, enhance their efficiency in gathering information as well as interacting with e-government.

The government and other decision makers should foster the involvement of different groups of men and women in the selection of priority public services and in the provision of feedback on their quality, including whether or not such services respond to women and men's actual needs.

The government should increase the presence and active participation of both men and women in equal measures in policy planning committees for national e-governance strategies and programmes since it is the first step towards creating a gender-responsive policy environment. This can be complemented by also having women and men involved in the formulation of national-level ICT for Development strategies which could also be linked to poverty reduction and other development plans

Also they should prioritize e-services that address the specific needs of women and men that are more responsive to gender equality issues. This is particularly relevant for local service delivery, since men and women within the counties usually have much closer contact with local government authorities than other levels of government and often have better opportunities to express their needs and concerns at the local level.

\subsection{Limitations and suggestions for future research}

In this study, only a small sample size of data was collected. The total number of usable sample in this study was 129 out of 149 questionnaires that had been distributed. Majority of the respondents were between 26 and 35 years old, which was more than half of the total respondents. $66.2 \%$ of females had education at tertiary level and $67.9 \%$ of male had education at tertiary level. This shows that majority of the respondents were either in college or university graduates These constraints might lead to difficulties to generalize the findings of this study to all level of citizens in Siaya county.

Another fact is that, this study is only confined to Siaya County. Hence, the sample of this study may not be a true representation of the significance of gender factor in Kenya as a whole towards using e-government service.

Future study is suggested to expand the scope of research to entire or half of Kenyan population in order to better understand the role of gender, design for e-governance policies and strategies perceived usefulness, perceived ease of use, Educational level, ICTs access and E-service delivery in egovernment adoption in Kenya as a whole.

Last but not least, this study is limited in that only one egovernment case has been presented. It is desired that in future, more cases will be analyzed and to the deepest detail. This will pave way for even testing of this model to ascertain its usefulness

\section{CONCLUSION}

To achieve successful adoption of e-government in Kenya, gender equality should be taken into account together with some important issues like design for e-governance policies and strategies and E-service delivery. The study shows that male gender is likely to be e-government services adopters compared to female. Though the margin difference is minimal, it is expected that future research will present a different outcome when it comes to gender and e-government adoption

Also, there are some obstacles facing the adoption of EGovernment services, most notably the ICT literacy, infrastructure, Awareness and gender equality. There should be a lot of awareness campaigns sensitizing the ordinary citizens on the benefits of e-government for them to fully adopt it and incorporate it as part of their culture. The findings show that both men and women are not conversant with e-citizen portal Development of local capacity and ICT skills for both genders should be addressed. This should also include raising awareness among women and men about the potential opportunities ICTs can create, in particular their role in helping citizens to participate in governance processes and to access information.

Recommendations and suggestions are outlined to help the Kenyan government and other key decision makers have a better understanding of mainstreaming gender in order to engender the adoption of e-government services.

\section{ACKNOWLEDGEMENTS}

I wish to thank my supervisor Dr Elisha Abade and the project panelists of Prof Elijah Omwenga and Dr Andrew Kahonge for their in-depth engagement, constructive criticism and useful insights that led to an acceptable successful work 


\section{REFERENCES}

[1] IST-Africa, Current ICT Initiatives and projects Republic of Kenya. Available from URL [https://www.istafrica.org/home/default.asp?page $=$ doc-byid\&docid=5181], accessed on 26/6/2015

[2] Ministry of information technology of Kenya (2014),About E-Government of Kenya, accessed on 26/8/2015 http://www.information.go.ke/?p=292

[3] Merrill Warkentin, David Gefen, Paul A. Pavlou \& Gregory M. Rose (2002), 'Encouraging Citizen Adoption of e-Government by Building Trust', pages 157-162, Volume 12, Issue 3

[4] Suha AlAwadhi, Anne Morris, 'Factors Influencing the Adoption of E-government Services', Journal of Software, VOL. 4, NO. 6, AUGUST 2009

[5] United Nations e-government survey 2014, accessed 12 April 2015, From URI http://unpan3.un.org/egovkb/Portals/egovkb/Documents/u n/2014-Survey/E-Gov_Complete_Survey-2014.pdf

[6] Shafi and Vishanth (2009), Investigating the Adoption of eGovernment Services in Qatar Using the UTAUT Model, Americas Conference on Information Systems, 2009 Proceedings, accessed on 17/05/2015 http://aisel.aisnet.org/cgi/viewcontent.cgi?article $=1260 \& \mathrm{c}$ ontext=amcis 2009

[7] Choudrie, J. and Y. Dwivedi (2005). A Survey of Citizens Adoption and Awareness of E-Government Initiatives, The Government Gateway: A United Kingdom Perspective. E-Government Workshop. Brunel University, West London.

[8] Venkatesh, V., Morris, M.G., Davis, F.D., and Davis, G.B "User Acceptance of Information Technology: Toward a Unified View," MIS Quarterly, 27, 2003, 425-478

[9] David Gefen, Detmar Straub (2000), 'the Relative Importance of Perceived Ease of Use in IS Adoption': A Study of E-Commerce Adoption Journal of the Association for Information Systems 1 Volume 1, Article 8

[10] Dwivedi, Y. and Weerakkody, V. (2007). Examining the factors affecting the adoption of broadband in the Kingdom of Saudi Arabia. Electronic Government, an International Journal, 4(1), 43-58.

[11] UN Women (2009),Gender mainstreaming, Accessed on 12/8/2015 from URL http://www.un.org/womenwatch/osagi/intergovernmental mandates.htm

[12] ATRCAD, African Training and Research Centre in Administration for Development, Report of the Seminar on 'Gender Mainstreaming in E-government' (2007)
Morocco, accessed on 5/01/2016, http:/unpan1.un.org/intradoc/groups/public/documents/caf $\mathrm{rad} / \mathrm{unpan} 026971 . \mathrm{pdf}$

[13] Bwalya K. J. and Healy, M. (2010) "Harnessing eGovernment Adoption in the SADC Region: a Conceptual Underpinning" Electronic Journal of e-Government Volume 8 Issue $12010,(p p 23$ - 32)

[14] Menda A. (2005) Successes and Challenges: EGovernance in Tanzania. Retrieved online on 22 July 2015 http://www.ftpiicd.org/iconnect/ICT4D_Governance/EN_ Governance_TA.pdf

[15] Brian, Bwalya, Kelvin Joseph (2009), 'Factors Affecting Adoption of E-government in Zambia'. The Electronic Journal of Information Systems in Developing Countries, Volume 38, No. 4.pp 1-13, on 22 October 2015 [http://www.ejisdc.org/ojs2/index.php/ejisdc/article/view/5 73/286]

[16] S. AL Awadhi and A. Morris (2008), the use of the UTAUT model in the adoption of e-government services in Kuwait, 41st Hawaii International Conference on System Sciences, Hawaii.

[17] S. E. Colesca \& L. Dobrica (2008), 'Adoption and use of e-government services: The case of Romania', International Journal of Social, Behavioral, Educational, Economic, Business and Industrial Engineering Vol:2, No:6, accessed on 5/9/2015, http://waset.org/publications/15361/e-governmentadoption-in-romania

[18] Agnieszka Z.,Elaine L.,R. Steele (2007), Towards understanding of factors influencing user acceptance of mobile payment systems, accessed on 17 October 2015, From

URL

https://opus.lib.uts.edu.au/bitstream/10453/7316/1/200404 L033.pdf

[19] Abel Gitau Mugenda, 2008, Social science research, theory and principles

[20] Cornford, T., and Smithson, S. Project Research in Information Systems: A Student's Guide, London: Macmillan Press, 1997.

[21] Israel, Glenn D, 1992, Determining Sample Size, accessed on $12 / 11 / 2015$ from URL http://www.tarleton.edu/academicassessment/documents/S amplesize.pdf

[22] Nadia Hijab and Raúl Zambrano (2007), UNDP, Gender Responsive E-governance: Exploring the Transformative Potential, accessed on 1/01/2016 [http://www.undp.org/content/dam/aplaws/publication/en/ publications/womens-empowerment/primers-in-genderand-democratic-governance 4/f_GenderGovPr_eG_Web.pdf] 